\title{
The Reasonableness Test of the Principal Purpose Test Rule in OECD BEPS Action 6 (Tax Treaty Abuse) versus the EU Principle of Legal Certainty and the EU Abuse of Law Case Law
}

\author{
Dennis Weber*
}

\section{Abstract}

The OECD BEPS Action 6 report contains a principal purpose test rule (PPT rule) for the purpose of combating abuse of tax treaties. This PPT rule is also included in the OECD Multilateral Instrument.

The PPT rule is (amongst others) applicable when 'it is reasonable to conclude' that a benefit (granted by a tax treaty) was one of the principal purposes of any arrangement/ transaction. This requirement contains two elements: the reasonableness test and the principal purpose test.

In literature it is observed that (i) the reasonableness test of the PPT rule could be contrary to the European Union's principle of legal certainty; (ii) that the OECD PPT rule gives the tax authorities too much discretion and, therefore, is not in line with EU law and (iii) there is doubt whether the OECD PPT rule contains a genuine economic activity test and therefore is in contravention of the abuse of law case law of the CJEU.

In this contribution, I defend that none of the above-mentioned reasons the OECD PPT rule is contrary to EU law. The only potential problem I see is that the OECD PPT rule is broader (no artificiality required) compared to the GAARs in Anti-Tax Avoidance Directive and the Parent-Subsidiary Directive.

Keywords: GAAR, abuse, tax avoidance, BEPS, principal purpose test, legal certainty

\section{Introduction}

The OECD BEPS Action 6 report contains a principal purpose test rule (PPT rule) ${ }^{1}$ for the purpose of combating abuse of tax treaties. This PPT rule is also included in the Multilateral Convention to implement tax treaty

Dennis Weber is a professor of European corporate tax law at the University of Amsterdam and director and founder of the Amsterdam Centre for Tax Law (ACTL).

1. See BEPS Action 6: Preventing the granting of treaty benefits inappropriate circumstances, OECD, 5 October 2015. related measures to prevent base erosion and profit shifting (often called MLI, the 'Multilateral Instrument').

The PPT rule is (amongst others) applicable when 'it is reasonable to conclude' that a benefit (granted by a tax treaty) was one of the principal purposes of any arrangement/transaction. This requirement contains two elements: the reasonableness test and the principal purpose test.

It is observed first in literature that the reasonableness test of the PPT rule could be contrary to the European Union's principle of legal certainty. ${ }^{2}$ Reference is made in this regard to the judgments of the Court of Justice of the European Union (CJEU) in $S I A T^{3}$ and Itelcar. ${ }^{4}$ Second, it is defended in literature that the OECD PPT rule gives the tax authorities too much discretion and, therefore, is not in line with EU law (based on the Biehl case). Third, there is doubt whether the OECD PPT rule contains a genuine economic activity test and therefore is in contravention of the abuse of law case law of the CJEU. 5

If the reasonableness test of the PPT rule is not in line with the EU principle of legal certainty or any other EU principle, this would mean that the EU Member States are not permitted to incorporate the PPT rule via the MLI or in another way in their bilateral tax treaties.

2. See E.C.C.M. Kemmeren, 'Where is EU Law in the OECD BEPS Discussion?' (editorial), 23(4) EC Tax Review 190 (2014) followed by: Kokolia and Chatziioakeimidou, 'BEPS Impact on EU Law: Hybrid Payments and Abusive Behaviour', ET, April 2015, at 155 and E. Pinetz, 'Final Report of Action 6 of the OECD/G20 Base Erosion and Profit Shifting Initiative: Prevention of Treaty Abuse', IBFD Bulletin 113 (2016).

3. CJEU 5 July 2012, Case C-318/10 (SIAT v État belge), ECLI:EU:C: 2012:415.

4. CJEU 3 October 2013, Itelcar, C-282/12

5. Fourth, in the literature the question is asked whether the fact that under the PPT rule there must be 'one of the principal purposes', whereas in the abuse case law of the CJEU it must concern a 'wholly artificial arrangement', is in contravention of EU law. I shall not discuss this in this contribution. See on this: D. Weber, 'The New Common Minimum Anti-abuse Rule in the EU Parent-Subsidiary Directive: Background, Impact, Applicability and Effect', 44(2) Intertax 98 (2016), paras. 6.1 and 6.2. 
In this contribution, I therefore discuss the question of whether the reasonableness test of the PPT rule is contrary to the EU principle of legal certainty. For this, I discuss the case law of the CJEU in this area and subject the cases SIAT and Itelcar, which are cited in the literature in order to defend that the PPT rule is contrary to the principle of legal certainty, to further examination, together with a number of other judgments of the CJEU.

\section{The Principal Purpose Test (PPT)}

\subsection{Introduction: The PPT Rule}

The PPT rule as is included in the MLI (the content of which is the same as the PPT rule which is incorporated in the OECD BEPS Action 6 report) reads as follows:

\section{Article 7-Prevention of Treaty Abuse}

1. Notwithstanding any provisions of a Covered Tax Agreement, a benefit under the Covered Tax Agreement shall not be granted in respect of an item of income or capital if it is reasonable to conclude, having regard to all relevant facts and circumstances, that obtaining that benefit was one of the principal purposes of any arrangement or transaction that resulted directly or indirectly in that benefit, unless it is established that granting that benefit in these circumstances would be in accordance with the object and purpose of the relevant provisions of the Covered Tax Agreement.

\subsection{The Reasonableness Test}

\subsubsection{An Objective Analysis of All Relevant Facts and Circumstances}

The PPT rule is applicable when it is reasonable to conclude, having regard to all relevant facts and circumstances, that obtaining that benefit was one of the principal purposes of any arrangement or transaction'. This requirement contains two elements: the reasonableness test and the principal purpose test. Although those two tests are distinct elements of the PPT rule, they are inextricably linked and, in my view, must be applied jointly.

The wording 'it is reasonable to conclude, having regard to all relevant facts and circumstances' is the so-called 'reasonableness test'. For the application of the reasonableness test in the PPT rule, points 10 and 11 of the Commentary on the PPT rule in the final report on Action 6 are of importance. These read as follows: ${ }^{6}$

10. To determine whether or not one of the principal purposes of any person concerned with an arrangement or transaction is to obtain benefits under the Convention, it is important to undertake an objective

6. See BEPS Action 6, above n. 1, paras. 10 and 11 of the Commentary on the PPT rule. analysis of the aims and objects of all persons involved in putting that arrangement or transaction in place or being a party to it. What are the purposes of an arrangement or transaction is a question of fact which can only be answered by considering all circumstances surrounding the arrangement or event on a case by case basis. It is not necessary to find conclusive proof of the intent of a person concerned with an arrangement or transaction, but it must be reasonable to conclude, after an objective analysis of the relevant facts and circumstances, that one of the principal purposes of the arrangement or transaction was to obtain the benefits of the tax convention. It should not be lightly assumed, however, that obtaining a benefit under a tax treaty was one of the principal purposes of an arrangement or transaction and merely reviewing the effects of an arrangement will not usually enable a conclusion to be drawn about its purposes. Where, however, an arrangement can only be reasonably explained by a benefit that arises under a treaty, it may be concluded that one of the principal purposes of that arrangement was to obtain the benefit.

11. A person cannot avoid the application of this paragraph by merely asserting that the arrangement or transaction was not undertaken or arranged to obtain the benefits of the Convention. All of the evidence must be weighed to determine whether it is reasonable to conclude that an arrangement or transaction was undertaken or arranged for such purpose. The determination requires reasonableness, suggesting that the possibility of different interpretations of the events must be objectively considered.

Reasonableness tests are common to common law systems ${ }^{7}$ for example, they are included in the General Anti-Tax Avoidance Rule (GAAR) of the UK (see also later), Australia, Canada and South Africa. ${ }^{8}$ By including a reasonableness test in a GAAR, the subjective intention that obtaining a tax benefit was the (main/ principal, etc.) purpose for a transaction, is objectified: ${ }^{9}$ to know the subjective intention of a taxpayer or arrangement, an objective analysis must be made of the (objective) facts and circumstances.

The subjective test in the PPT rule (the principal purpose) is objectified by the reasonableness test: ${ }^{10}$ it is reasonable to conclude [means: objective analysis], having regard to all relevant facts and circumstances' [means: objective facts and circumstances]. (emphasis added)

7. Reasonableness tests are also used outside of tax law, for example, 'a reasonable doubt' in UK, US and Canadian criminal law.

8. See P. Rosenblatt, General Anti-Avoidance Rules for Major Developing Countries, Kluwer Law International (2014), para. 3.2.1.

9. See R. Krever, 'General Report: GAARs', published in GAARS - A Key Element of Tax Systems in the Post-BEPS, European and International Tax Law and Policy Series, No. 3, IBFD (2016), in para. 1.4. 'taxpayer's purpose'.

10. See also Reinout Kok, 'The Principal Purpose Test in Tax Treaties Under BEPS 6', 44(5) Intertax (2016), at 406. 
That the reasonableness test is an objective test is clearly worded in the Commentary to the PPT: ${ }^{11}$

to determine whether or not one of the principal purposes of any person concerned with an arrangement or transaction is to obtain benefits under the Convention, it is important to undertake an objective analysis of the aims and objects of all persons involved in putting that arrangement or transaction in place or being a party to it. What are the purposes of an arrangement or transaction, is a question of fact, which can only be answered by considering all circumstances surrounding the arrangement or event on a case-by-case basis. It is not necessary to find conclusive proof on intent of a person concerned with an arrangement or transaction, but it must be reasonable to conclude after an objective analysis of the relevant facts and circumstances, that one of the principal purposes of the arrangement or transaction was to obtain the benefits of the tax convention. (emphasis added)

It is also remarked in point 11 of the Commentary that all relevant facts and circumstances (the evidence) 'must be weighed to determine whether it is reasonable to conclude that an arrangement or transaction was undertaken or arranged for such purpose'. In my view, substance can only be given to the wording, can 'be weighed', when the tax authorities substantiate with reasons in the assessment how the various facts and circumstances relate to each other.

Furthermore, in point 11 of the Commentary, it is observed that 'The determination requires reasonableness, suggesting that the possibility of different interpretations of the events must be objectively considered'. In my view, this should be interpreted such that in the interpretation of the 'facts and circumstances' these must be interpreted such as a reasonable (third) person would have interpreted those facts and circumstances. The analysis of the facts and circumstances is therefore also objective.

The assessment of the tax authorities that obtaining a tax benefit was one of the principal purposes of a transaction must thus be based on:

- all relevant facts and circumstances

- which must be weighed

- in an objective analysis

It can be gathered from this that this assessment is not an easy test. That is also emphasised in the Commentary. In point 10 , it is remarked: 'It should not be lightly assumed' (emphasis added) and in that regard, it is pointed out that 'merely reviewing the effects of an arrangement will not usually enable a conclusion to be drawn about its purposes' (emphasis added). It is shown from this that the tax authorities may not assume that a tax benefit is the principal purpose of an arrangement to obtain a treaty benefit, but also that they may not only point out the effects in their assessment so to come to the

11. See BEPS Action 6, above n. 1, para. 10 of the Commentary on the PPT rule. conclusion that the principal purpose of an arrangement is to obtain a treaty benefit. The tax authorities may thus, for example, not point out a large tax benefit and from that, draw the conclusion that obtaining that benefit was one of the principal purposes of an arrangement or transaction. On the other hand, the taxpayer may not merely assert this. In point 11 of the Commentary it is observed in this regard: 'A person cannot avoid the application of this paragraph by merely asserting that the arrangement or transaction was not undertaken or arranged to obtain the benefits of the Convention.'

In the Commentary on the OECD PPT rule, several examples are given. As an example that the OECD PPT rule is not applicable, a reference is made to the situation that a certain shareholding in a company is 'related to the expansion' of the shareholders 'business and lower manufacturing costs'. ${ }^{12}$ In another example, the OECD PPT rule is not applicable because there is the establishment of a regional group services company that has a 'real business', whereby the service company 'exercises substantive economic functions, using real assets and assuming real risk' and that the business is carried on by the company 'through its own personnel'. ${ }^{13}$ In the OECD Action 6-report is also a reference to 'valid commercial reasons'. ${ }^{14}$ It appears from the examples given in the Commentary that many different facts and circumstances must be weighed against each other in order to reach the conclusion on whether there is or is not treaty abuse. It also appears from this that the PPT rule requires an in-depth study of the facts and circumstances, and that nothing may be based on assumptions.

\subsubsection{Comparable Reasonableness Test in UK GAAR}

As mentioned above, the reasonableness test is often included in GAARs in common law systems. In 2013, a GAAR was introduced in the $\mathrm{UK}$, and although there is nothing to show that the OECD PPT rule is based on the UK GAAR, their reasonableness tests are similar. The reasonableness test in the UK GAAR reads: ${ }^{15}$ "Arrangements are "tax arrangements" if, having regard to all the circumstances, it would be reasonable to conclude that the obtaining of a tax advantage was the main purpose, or one of the main purposes, of the arrangements' (emphasis added). The following observation is made on this in the HMRC GAAR Guidance: ${ }^{16}$

12. Preventing the granting of treaty benefits in inappropriate circumstances, Action 6: final report, OECD/G20 Base Erosion and Profit Shifting project, 5 October 2015, Commentary on the PPT rule: point 14, example $\mathrm{C}$ (manufacturing plant in developing country).

13. Preventing the granting of treaty benefits in inappropriate circumstances, Action 6: final report, OECD/G20 Base Erosion and Profit Shifting project, 5 October 2015, Commentary on the PPT rule: point 14, example G.

14. Preventing the granting of treaty benefits in inappropriate circumstances, Action 6: final report, OECD/G20 Base Erosion and Profit Shifting project, 5 October 2015, Commentary on the PPT rule: point 8.

15. Art. 207(1) Finance Act 2013.

16. HM Revenue and Customs (HMRC) General Anti Abuse Rule (GAAR) guidance (Approved by the Advisory Panel with effect from 30 January 2015), c.3.3 
The expression 'reasonable to conclude' shows that this is an objective test, which is to be applied by taking into account all the relevant circumstances and asking whether, in the light of those circumstances, a reasonable conclusion would be that obtaining a tax advantage was the main purpose, or one of the main purposes, of the arrangements. It is neither necessary nor appropriate to enquire whether any particular person (for example the taxpayer himself, or a promoter of the arrangements, if there was one) actually had that intention. In practice, though, it would be very rare to find a situation where objectively the obtaining of a tax advantage appeared to be one of the main purposes of an arrangement although, subjectively, the participators did not in fact have any such aim. (emphasis added)

Also here we see clearly that the reasonableness test is an objective test in which the subjective intention of the taxpayer is derived from objective circumstances and that it must concern a 'reasonable conclusion'.

\subsubsection{Different Interpretation in Literature}

In literature, a different interpretation of the reasonableness test is also defended. Lang writes: ${ }^{17}$ 'On the other hand, the requirements are not too demanding - it must be merely "reasonable": but not, for instance, compelling. Therefore, the tax authority does not need to produce full evidence thereof". Bhargava also observes that "the tax authorities will find it easier to prove" "as the threshold that is set out is very low ("reasonable to conclude")'. ${ }^{18}$ And Pinetz: ${ }^{19}$ 'the requirements are (...) quite lenient, as it need only be reasonable to conclude'. I do not agree with this interpretation. In my view, the wording 'reasonable to conclude' does not mean the meight of the burden of proof on the tax authorities, but it means that the assessment of the tax authority must be obtained through an objective analysis based on facts and circumstances (and it has to weigh all facts and circumstances; may thus not be based on an assumption; or only refer to the tax advantage as such).

Lang writes: ${ }^{20}$ 'In practice, furnishing evidence of the motives will therefore not be relevant, but the tax authorities will be tempted to presume intention simply because of the presence of a benefit' (emphasis added). Pinetz also notes that 'the wording of the provision proposed by the OECD makes it easy for tax authorities to assume abuse' (emphasis added). In my view, that is not what the PPT rule prescribes. The reasonableness test in the OECD PPT rule prescribes an objective analysis of all relevant facts and circumstances, such as this is,

17. M. Lang, BEPS Action 6: Introducing an antiabuse rule in tax treaties, Tax Notes International, 655, at 658.

18. A. Bhargava, 'The Principal Purpose Test: Functioning, Elements and Legal Relevance', in Blum and Seiler (eds.), Preventing Treaty Abuse, Series on International Tax Law (2016), 311, at 318.

19. Pinetz, above n. 2, at 116. See also E. Pinetz, 'Use of the Principal Purpose Test to Prevent Treaty Abuse', in Lang et al. (eds.), Base Erosion and Profit Shifting (BEPS), Series on International Tax Law (2016), Linde, at 271

20. Lang, above n. 17. often to be found in GAARs in common law systems, and from the OECD Commentary it is clearly observed (see also here above) that an assessment that is based on an assumption or is only based on the effect of an arrangement (the tax benefit) is not sufficient.

In literature, moreover, it is noted that the subjective test in the PPT rule cannot be rebutted by proving that valid commercial reasons exist for the transaction. ${ }^{21}$ In my view this is incorrect. The PPT rule requires that the tax authorities determine, by means of the reasonableness test, the principal purpose of the transaction. When the tax authorities come to the conclusion on the basis of the facts and circumstances at their disposal that the principal purpose of an arrangement is to obtain a tax benefit, then the taxpayer can always dispute this in an objection against his tax assessment or before a court. In that regard, the taxpayer can thus put forward the relevant facts and circumstances. In addition, in practice, before they apply the PPT rule, in most situations the tax authorities will request the taxpayer by letter to provide relevant facts and circumstances. In such a case, the taxpayer can thus provide his economic reasons (based on facts and circumstances) for an arrangement. When the tax authority only applies the PPT rule on the basis of the fact that there is a tax benefit, then the application of the PPT rule must, in my view, be refused by a national court. It is shown from the Commentary, namely, that on the basis of solely the 'effect' of an arrangement, the PPT rule may not be applied.

\subsection{EU-Problems in Literature}

In literature, it is remarked that the reasonableness test of the PPT rule is contrary to the principle of legal certainty. Kemmeren ${ }^{22}$ remarks on this that the reasonableness test 'may create too much uncertainty to taxpayers'. He refers particularly to the Itelcar case in which the CJEU ruled on whether national legislation was in line with the requirement of legal certainty. His analysis would seem to be endorsed by Kokolia/Chatziioakeimidou $^{23}$ and Pinetz. ${ }^{24}$ Baker examines the reasonableness test of the PPT rule also on compatibility with the EU principle of legal certainty. ${ }^{25} \mathrm{He}$ too mentions in that regard the judgments of the CJEU in SIAT and Itelcar. He subsequently compares the PPT rule with the comparable anti-abuse rule such as is included in the

21. See O. Koriak, 'The Principal Purpose Test Under BEPS Action 6: Is the OECD Proposal Compliant with EU Law?' ET (2016), at 552 and C. Panayi, 'The Compatibility of the OECD/G20 Base Erosion and Profit Shifting Proposals with EU Law', 1(2) IBFD Bulletin 95 (2016).

22. Kemmeren, above n. 2 .

23. Kokolia and Chatziioakeimidou, above n. 2 and Pinetz, above n. 2.

24. Pinetz, above n. 2.

25. P. Baker, The BEPS Action Plan in the light of EU Law: Treaty Abuse, 2015 BTR, no 3, at 408. 
Parent-Subsidiary Directive ${ }^{26}$ and notes that the PPT rule and this anti-abuse rule are comparable, and that it can be assumed that the anti-abuse rule of the ParentSubsidiary Directive is in accordance with Union law. ${ }^{27}$ On the basis thereof, he comes to the conclusion that, 'it is a reasonable observation that the proposed PPT is not significant less precise or clear than this general antiavoidance rule inserted into the parent-subsidiary directive'. Baker, therefore, sees no contravention of the principle of legal certainty.

\section{The Principle of Legal Certainty in the (Tax) Case Law of the Court of Justice of the EU}

\subsection{Knowledge of Legal Rules and Foreseeability} of Legal Situations

The principle of legal certainty is a fundamental principle of EU law ${ }^{28}$ and serves to ensure that legal rules are clear and precise and also that the legal situations and relationships governed by Community law are foreseeable (see Duff). ${ }^{29}$ Accordingly, the principle safeguards the ability of interested parties to ascertain what their legal rights and obligations are at a certain moment, which in turn ensures that they can be certain as to the legal and economic consequences of their actions. ${ }^{30} \mathrm{In}$ Van $E s,{ }^{31}$ it was considered that 'the principle of legal certainty is a fundamental principle of Community law (...) which requires in particular that rules imposing charges on a taxpayer be clear and precise so that he may be able to ascertain unequivocally what his rights and obligations are and take steps accordingly. ${ }^{32}$ In the Van Es judgment (a customs case), a Regulation could not be applied to certain tax assessments because the Commission had not adjusted this Regulation and, as a result, a taxpayer was unable to precisely determine his legal position.

26. Art. 1(2) of the Parent-Subsidiary Directive lays down that: 'Member States shall not grant the benefits of this Directive to an arrangement or a series of arrangements that, having put into place for the main purpose or one of the main purposes of obtaining a tax advantage which defeats the object or purpose of this Directive, are not genuine having regard to all relevant facts and circumstances'. See Council Directive (EU) 2015/121 of 27 January 2015 amending Directive 2011/96/EU on the common system of taxation applicable in the case parent companies and subsidiaries of different Member States \{2015\} OJ L21/1.

27. See also para. 61 of Weber (2016), above n. 5 .

28. ECJ 21 September 1983, joined cases 205/82-215/82 (Deutsche Milchkontor), ECR 1983, at 2633 (Opinion VerLoren van Themaat).

29. See CJEU 15 February 1996, case C-63/93 (Duff), ECR I-569 (Opinion Cosmas), para. 20.

30. Cf. AG Cosmas in his Opinion to ECJ 15 February 1996, case C-63/93 (Duff), ECR I-569, paras. 23 through 25.

31. CJEU 13 February 1996, case C-143/93 (Van Es), ECR I-431 (Opinion Elmer).

32. Id., para. 27

\subsection{The Principle of Legal Certainty in Tax Cases}

The principle of legal certainty has been the subject of discussion in a number of (tax) cases.

\subsubsection{Commission/Greece}

In Commission/Greece, ${ }^{33}$ the question was whether Directive 69/335/EEC concerning indirect taxes on the raising of capital ${ }^{34}$ had been implemented correctly into Greek domestic legislation. The discussion in the case concerned the question whether the domestic law that charged capital duty on intra-EU transfers of the effective centre of management or registered office insofar as the company concerned is not subject to capital duty in the Member State of origin, is in line with Directive 69/335/EEC. Of importance in this regard is that the CJEU remarked in paragraph 24:

While the Hellenic Republic acknowledges that this distinction has not been clearly drawn until now and may have led to a degree of confusion, it nevertheless considers that the criterion of being 'subject to' duty is in accordance with the 'capital company' criterion prescribed by Directive 69/335 and thus correctly transposes Article 4(1)(g) and (h) and (3)(b) of the directive.

In the judgment, the CJEU explained why it was of the opinion that the Greek implementation was contrary to Directive 69/335/EEC. Subsequently, in paragraph 33, it added:

Furthermore, inasmuch as the Hellenic Republic acknowledges that the distinction between 'actual taxation' and being 'subject to' duty was not clearly made in the transfer rules at issue and may have led to a degree of confusion, it should be added that, in any event, such rules do not satisfy the requirements established by the case-law concerning transposition of directives. According to that case-law, it is particularly important, in order to satisfy the requirement for legal certainty, that individuals should have the benefit of a clear and precise legal situation enabling them to ascertain the full extent of their rights and, where appropriate, to rely on them before the national courts (see to this effect, in particular, Case C-236/95 Commission v Greece [1996] ECR I-4459, paragraph 13, and Case C-177/04 Commission v France [2006] ECR I-2461, paragraph 48). The rules cannot be regarded as establishing a clear and precise legal situation of that kind.

It appears from the judgment that Greece 'acknowledges' that the domestic law was not clear and led to 'a degree of confusion'. Greece thus conceded that, in fact, its domestic law was contrary to the principle of legal

33. ECJ 7 June 2007, case C-178/05 (Commission/Greece), ECR I-4185

34. Council Directive 69/335/EEC of 17 July 1969 concerning indirect taxes on the raising of capital (OJ, English Special Edition 1969 (II), at 412), as amended by Council Directive 85/303/EEC of 10 June 1985 (OJ 1985 L 156, at 23) ('Directive 69/335'). 
certainty. For the CJEU thus, a piece of cake: the CJEU itself did not establish that the domestic legislation was not clear and did not precisely reflect the rights of a taxpayer, but based itself on the statements of the Member State. The arguments on the principle of legal certainty are also used by the CJEU as extra argument to deem the national law not in line with EU law.

\subsubsection{SIAT}

One direct taxation case in which the CJEU found a national anti-abuse law not in line with the principle of legal certainty is $S I A T$. $^{35}$

This case concerned a Belgian deduction of expenses limitation, which denied a deduction for a payment for performances or services if they were paid to a non-resident company, where the non-resident company was not subject, in the Member State of establishment, to tax on income or was subject, as regards the relevant income, to a tax regime that is appreciably more advantageous than the applicable regime in Belgium. In such a situation, the payments were not deductible unless the taxpayer could prove that such payments related to genuine and proper transactions and did not exceed the normal limits, whereas, under the general domestic rule, such payments were to be regarded as deductible business expenses if they were necessary for acquiring or retaining taxable income and if the taxpayer demonstrated the authenticity and amount of such expenses.

The CJEU considered this rule a restriction on the free movement of services. With regard to the justification grounds, the Court observed (paragraph 48):

It must therefore be held that legislation such as that at issue in the main proceedings is suitable for attaining the objectives of preventing tax evasion and avoidance and of preserving both the effectiveness of fiscal supervision and the balanced allocation between Member States of the power to impose taxes, all of which - as is apparent from the foregoing - are closely linked in the case before the referring court.

The Court then examined whether or not that legislation goes beyond what is necessary in order to attain those objectives. Under this proportionality test, the Court followed the strict line of reasoning it had established under the anti-abuse case law. Of particular importance is that the Court considered (paragraph 50):

It is clear from the case law of the Court that, where legislation is predicated on an assessment of objective and verifiable elements for the purposes of determining whether a transaction represents a wholly artificial arrangement entered into solely for tax reasons, it may be regarded as not going beyond what is necessary to prevent abusive practices, if, on each occasion on which the existence of such an arrangement can-

35. SIAT (C-318/10), the analysis in this case is partly based on one of my previous analyses on this case, which was published in para. 5.3 of D. Weber, 'Abuse of Law in European Tax Law: An Overview and Some Recent Trends in the Direct and Indirect Tax Case Law of the ECJ', part 2, IBFD European Taxation 313 (July 2013). not be ruled out, that legislation gives the taxpayer an opportunity, without subjecting him to undue administrative constraints, to provide evidence of any commercial justification that there may have been for that arrangement.

Here, the Court referred to paragraph 82 of the Test Claimants in the Thin Cap Group Litigation-case. This was nothing new but was simply a reiteration of old case law. The Court then went on to test whether or not the Belgian rule satisfied the above requirements. The Court considered the following (paragraphs 54-58):

54 However, as has been indicated in paragraph 25 above, the special rule may be applied where payments are made to providers who, by virtue of the legislation of the Member State in which they are established, are not subject there to a tax on income or are subject there, for the relevant income, to a tax regime which is appreciably more advantageous than the applicable regime in Belgium.

55 Accordingly, as the Advocate General noted in point 71 of his Opinion, the special rule requires the Belgian taxpayer to provide, as a matter of course, proof that all the services are genuine and proper and that all related payments are normal, without the tax authority being required to provide even prima facie evidence of tax evasion or avoidance.

56 The special rule can be brought to bear without any objective criterion, verifiable by a third party, being applied to test for the existence of a wholly artificial arrangement which does not reflect economic reality and which has been made with the aim of escaping the tax normally due on the profits generated by activities carried out in the national territory, since account is taken only of the level of tax imposed on the service provider in the Member State in which that provider is established.

57 It must be stated that, as has been noted in paragraph 27 above, a rule framed in such terms does not make it possible, at the outset, to determine its scope with sufficient precision and its applicability remains a matter of uncertainty.

58 Such a rule does not, therefore, meet the requirements of the principle of legal certainty, in accordance with which rules of law must be clear, precise and predictable as regards their effects, in particular where they may have unfavourable consequences for individuals and undertakings (see, to that effect, Case C-17/03 VEMW and Others [2005] ECR I-4983, paragraph 80, and Joined Cases C-72/10 and C-77/10 Costa and Cifone [2012] ECR I-0000, paragraph 74). As it is, a rule which does not meet the requirements of the principle of legal certainty cannot be considered to be proportionate to the objectives pursued.

In paragraph 57, the Court referred to paragraph 27 of the decision. The Court stated the following in paragraphs 26-28: 
26 As the Belgian Government acknowledges, in the absence of a statutory definition, or administrative instructions as to what is to be understood by 'a tax regime which is appreciably more advantageous than the applicable regime in Belgium', the assessment concerning the applicability of the special rule is carried out on a case-by-case basis by the tax authority, under the supervision of the national courts.

27 In those circumstances, the scope of that special rule is not delimited with sufficient precision at the outset and, in a situation where the service provider is established in a Member State other than the Kingdom of Belgium and is subject there to a tax regime which is more advantageous than the applicable regime in Belgium, there is uncertainty as to whether the foreign regime will be considered to be a 'regime which is appreciably more advantageous' and whether, as a result, the special rule will apply.

28 Accordingly, that special rule - which lays down stricter conditions for being allowed to deduct business expenses than those laid down in the general rule and the scope of which has not been delimited with precision beforehand - is liable both to dissuade Belgian taxpayers from exercising their right to the freedom to provide services and from making use of the services of providers established in another Member State and to dissuade those providers from offering their services to recipients established in Belgium (see, to that effect, Case C-422/01 Skandia and Ramstedt [2003] ECR I-6817, paragraph 28 and the caselaw cited).

In $S I A T$, the Court rejected a general anti-abuse rule that reverses the burden of proof in regard to the deduction of expenses (places it on the taxpayer) where the payments to the recipients fall under a 'a tax regime which is appreciably more advantageous than the applicable regime in Belgium' on the basis of the fact that such a measure is too general and is contrary to the principle of legal certainty.

As concerns the opinion that the Belgian law is contrary to the principle of legal certainty, ${ }^{36}$ we see that the CJEU, just as in Commission/Greece, bases itself on statements of the Member State on the interpretation of the national law. In paragraph 26, the CJEU considers, namely, that

As the Belgian Government acknomledges, in the absence of a statutory definition, or administrative instructions as to what is to be understood by 'a tax regime which is appreciably more advantageous than the applicable regime in Belgium,' the assessment concerning the applicability of the special rule is carried out on a case-by-case basis by the tax authority, under the supervision of the national courts. (emphasis added)

36. Here, I make no observations on the reasoning of the CJEU that the Belgian rule was too general (that rule was indeed too general, but in my view for other reasons than those given by the CJEU in SIAT); see further: Weber (2013), above n. 35.
The CJEU, 'in those circumstances', is of the opinion that 'the scope of that special rule is not delimited with sufficient precision at the outset' and 'there is uncertainty as to whether the foreign regime will be considered to be a 'regime which is appreciably more advantageous'and whether, as a result, the special rule will apply' (see paragraph 27). We see thus both in Commission/Greece and in SIAT that the CJEU follows the qualification of the Member State that a national rule leads to uncertainty because this is not clear ('not clearly') (Commission/Greece); or is unclear by the absence of a statutory definition, or because of absence of instructions (SIAT) or it leads to 'a degree of confusion' (Commission/Greece).

\subsubsection{Itelcar}

The Itelcar judgment ${ }^{37}$ concerns Portuguese thin capitalisation legislation. On the basis of this legislation, interest paid between companies between which 'special relations' exist is under certain conditions excluded from deduction from the profit in Portugal. The EU law issue was that interest paid to a lender established in a third country (in the case of Itelcar, the United States) is excluded from deduction, but if the lender was established in Portugal, the interest was always deductible. According to the CJEU, this was a restriction of the free movement of capital between the Member States and third countries. The next question was whether such a restriction may be justified by an overriding reason in the public interest. The Portuguese Government argued that the rules intended

to combat tax evasion and avoidance by preventing the practice of 'thin capitalisation', which consists of eroding the basis of assessment for corporation tax in Portugal through the payment of interest, which is deductible, instead of profits, which are not deductible. That practice involves the arbitrary transfer of taxable revenues from that Member State to a nonmember country, as a result of which the profits of a company are not taxed in the State in which those profits have been generated.

In that connection, the CJEU recalled the settled caselaw that

a national measure restricting the free movement of capital may be justified where it specifically targets wholly artificial arrangements which do not reflect economic reality and the sole purpose of which is to avoid the tax normally payable on the profits generated by activities carried out on the national territory. (paragraph 34)

Subsequently, the CJEU ruled that 'such rules are an appropriate means of attaining the objective of combatting tax evasion and avoidance'. Finally, the CJEU examined whether the Portuguese rules did not go 
beyond what is necessary in order to attain that objective. In that regard, the CJEU reiterated its case law that

where rules are predicated on an assessment of objective and verifiable elements for the purposes of determining whether a transaction represents a wholly artificial arrangement entered into for tax reasons alone, they may be regarded as not going beyond what is necessary to prevent tax evasion and avoidance, if, on each occasion on which the existence of such an arrangement cannot be ruled out, those rules give the taxpayer an opportunity, without subjecting him to undue administrative constraints, to provide evidence of any commercial justification that there may have been for that transaction. (paragraph 37)

The CJEU found first, that the Portuguese legislation provided for such an opportunity to provide proof (paragraph 39). Subsequently, the CJEU saw another problem. In that regard, the CJEU considered the following:

41 As can be seen from paragraph 20 above, the term 'special relations', as defined in Article 58(4) of the CIRC, encompasses situations that do not necessarily involve the lending company of a non-member country holding shares in the resident borrowing company. Where there is no such shareholding, the effect of the method for calculating the excess indebtedness laid down in Article 61(3) of the CIRC is that any credit arrangement between those two companies falls to be regarded as excessive.

42 It is clear that, in the circumstances described in the paragraph above, the rules at issue in the main proceedings also affect conduct the economic reality of which cannot be disputed. In presuming that, in such circumstances, the basis of assessment for corporation tax payable by the resident borrowing company is being eroded, those rules go beyond what is necessary to attain their objective.

43 Moreover, in so far as the rules at issue in the main proceedings are applied - in accordance with the statements made by the Portuguese Government, as summarised in paragraph 21 above - only to situations in which the lending company has a direct or indirect shareholding in the borrowing company, so that the situation referred to in paragraph 41 above does not arise, the fact remains that such a limitation on the scope of those rules does not follow from their wording, which tends, on the contrary, to suggest that they do cover special relations where there is no such shareholding.

44 That being so, the rules in question do not make it possible, at the outset, to determine their scope with sufficient precision. Accordingly, they do not meet the requirements of legal certainty, in accordance with which rules of law must be clear, precise and predictable as regards their effects, especially where they may have unfavourable consequences for individuals and companies. As it is, rules which do not meet the requirements of the principle of legal certainty cannot be considered to be proportionate to the objectives pursued. (see $S I A T$, paragraphs 58 and 59)

It follows from those considerations that the Portuguese provision contains some 'overkill'. The anti-abuse rule is namely also applicable when a loan is provided by a third party (which has no shares in the recipient of the loan); in situations with third parties, the Portuguese thin capitalisation rule leads to the conclusion that each debt between the lender and the borrower must be considered excessive due to which the interest was not deductible. The Portuguese Government contradicted this interpretation of the Portuguese provision and observed that the anti-abuse provision was only applicable to situations in which the lending company has a direct or indirect shareholding in the borrowing company. On this, the CJEU considered that 'such a limitation on the scope of those rules does not follow from their wording, which tends, on the contrary, to suggest that they do cover special relations where there is no such shareholding'; to subsequently consider (paragraph 44):

That being so, the rules in question do not make it possible, at the outset, to determine their scope with sufficient precision. Accordingly, they do not meet the requirements of legal certainty, in accordance with which rules of law must be clear, precise and predictable as regards their effects, especially where they may have unfavourable consequences for individuals and companies. As it is, rules which do not meet the requirements of the principle of legal certainty cannot be considered to be proportionate to the objectives pursued (see $S I A T$, paragraphs 58 and 59).

In Itelcar, we see an anti-abuse provision, which is clearly applicable in the case the lending company is a third party (that will say the lending company had no direct or indirect shareholding in the borrowing company). The Portuguese Government alleged, however, that the rule could only be applied where there was a matter of a direct or indirect shareholding, thus not in the case of a third party. Because this interpretation of the Portuguese rule was in contravention of the clear legislative text, the CJEU observed that the Portuguese rules were not in line with the requirements of legal certainty because the scope of the regulations could not be established with sufficient precision. The similarity of this case with Commission/Greece and SIAT is that in those cases, the CJEU also based their interpretation of the principle of legal certainty on statements of the relevant Member State. It can be derived from these cases that when the Member State concedes to the CJEU that a certain legislative text gives reason for uncertainty, the CJEU declares the legislation contrary to the principle of legal certainty. 


\section{Reasonableness Test in Breach of the EU Principle of Legal Certainty?}

The matter which is researched in this article is whether the reasonableness test in the PPT rule is contrary to the EU principle of legal certainty; here I discuss that from various points of view.

\subsection{Commission/Greece; SIAT and Itelcar}

As has been mentioned above, reference is made in literature especially to SIAT and Itelcar for the substation that the reasonableness test of the PPT rule is contrary to the principle of legal certainty. In this regard, it is remarked that the PPT rule brings too much uncertainty and that, after citing the grounds from SIAT and Itelcar, is thus contrary to the principle of legal certainty. No further substantiation is given. In my view, this interpretation takes the rulings in SIAT and Itelcar about the principle of legal certainty out of their context. When they are read in the context of the case, one must come to the conclusion that those cases cannot be applied to the PPT rule: As I have demonstrated in Section 4 of this article, the CJEU did not independently come to the conclusion in SIAT or Itelcar or Commission/Greece, that the national legislation in those cases was contrary to the principle of legal certainty. The CJEU only came to this conclusion because the Member

State itself had admitted that the rule was not clear, precise and predictable. Furthermore, in all those cases, contravention with the legal principle of legal certainty was an extra argument to deem the provision contrary to EU law.

\subsection{Is Independent Invoking of the Principle of Legal Certainty Possible?}

The authors in literature who defend that the reasonableness test is contrary to the principle of legal certainty assume that when the PPT rule is applicable, the principle of legal certainty such as applied in the case law of the CJEU can be invoked. In the cases discussed here in Section 4, we see that in those cases, another contravention of EU law was also at issue: in Commission/Greece Directive 69/335/EEC, in SIAT and Itelcar the EU Treaty freedoms.

The PPT rule does not appear to me to be in contravention of the EU Treaty freedoms. Assume that the PPT rule is applicable, then that would mean that the benefits under the relevant tax treaty would not be granted. This could then mean juridical double taxation arises. Juridical double taxation, however, on the basis of cases such as Kerckhaert-Morres, ${ }^{38}$ does not constitute a restriction of the EU Treaty freedoms but is a 'result from the exercise in parallel by two Member States of their fiscal sovereignty'. ${ }^{39}$

The question remains whether the principle of legal certainty can be invoked independently, also if the remaining EU law is not applicable. To me, in principle, this would seem impossible. In order to invoke the EU principle of legal certainty, EU law as such must first be applicable.

4.3 Reasonableness Test to be Found in the Case Law of the CJEU Itself: The Objectified Intention/Genuine and Economic Realitytest

\subsubsection{Reasonableness Test and Abuse Test in the Case Law of the CFEU: Comparable}

The reasonableness test requires that the tax authority must make on the basis of all facts and circumstances an objective analysis that obtaining a benefit is one of the principal purposes of an arrangement. The subjective intention (principal purpose) is hereby derived from this objective analysis. We see a similar test, which can also be called the 'objectified intention test ${ }^{40}$ in the abuse of law case law of the CJEU. One example is the Halifax case (a VAT case) in which for the application of the subjective intention, the CJEU observed that the 'essential aim of the transactions' (emphasis added) must be examined. In Weald leasing, another VAT case, the CJEU considered (paragraph 30): 'Second, it must also be apparent from a number of objective factors that the essential aim of the transactions concerned is to obtain a tax advantage'. In Thin Cap $G L O,{ }^{41}$ a direct taxation case, the CJEU considered (paragraph 82): 'national legislation which provides for a consideration of objective and verifiable elements in order to determine whether a transaction represents a purely artificial arrangement, entered into for tax reasons alone' (emphasis added). The objectified intention test is elaborated further in the case law of the CJEU in the genuine test (also called the economic reality test). In the Cadbury Schmeppes-case, ${ }^{42}$ the CJEU considered in that regard that abuse existed when there were 'wholly artificial arrangements which do not reflect economic reality'. For this, it must be examined whether there were 'objective circumstances' (paragraph 64) that reflect an 'economic reality' (paragraph 65); the CJEU pointed out in that regard to 'objective factors which are ascertainable by third parties with regard, in particular, to the extent to which the (company) physically exists in terms of premises, staff and equipment' (paragraph 67). From Cadbury Schmeppes, it is also shown that only pointing out a tax benefit is not sufficient to come to the conclusion that

Different: Koriak, above n. 21; Koriak is of the opinion that there is restriction, but in that regard, does not discuss the Kerckhaert-Morres case, a case that points to another direction. I therefore do not agree with his analyses.

40. See Weber (June 2013), above n. 35, part 1, at 253

41. CJEU 13 March 2007, case C-524/04, Thin Cap GLO.

42. CJEU September 2006, case C-196/04, Cadbury Schweppes. 
this is abuse. ${ }^{43}$ It is shown from, amongst others, the Foggia case ${ }^{44}$ that to answer the question of whether abuse is present, all circumstances must be weighed against each other. A tax benefit (in that case, large losses) cannot in itself be considered decisive (paragraph 39 of Foggia): 'However, the fact that those tax losses are very substantial and that their origin has not been clearly determined may constitute an indicator of tax evasion or avoidance', according to the CJEU. As is shown from Foggia, abuse can be even present when an arrangement is not artificial. When the tax benefits are much higher than the (genuine) economic benefit, ${ }^{45}$ after having weighed those facts against each other, one can come to the conclusion that the principal purpose of an arrangement is to obtain a tax benefit, even if nothing is artificial.

In my view, the economic reality test that can be found in the case law of the CJEU is comparable to the reasonableness test in de OECD PPT rule. ${ }^{46}$ In the economic reality test, namely, account is also taken of (i) all relevant facts and circumstances (see, for example, Thin Cap GLO); (ii) which must be weighed (Foggia); (iii) in an objective analysis (Cadbury Schmeppes: artificial versus economic reality/genuine); the last objective analysis is present in the case law of the CJEU given that it must be determined whether an arrangement is 'wholly artificial' or if it concerns a 'genuine' arrangement. This should be subjected to an objective assessment: what is genuine in such a situation? What is artificial in such a situation? The answer to this is, to ask yourself what a third (reasonable) person in such a situation should do. This is comparable with the OECD PPT rule: in point 11 of the Commentary it is remarked that 'the determination requires reasonableness suggesting that the possibility of different interpretations of the events must be objectively considered'. It follows from the Commentary, in my view, that the 'facts and circumstances' must be interpreted such as a reasonable (third) person would have interpreted those facts and circumstances. If a reasonable person should qualify certain facts and circumstances as artificial, then the principal purpose of a transaction will have been to obtain a tax benefit. This means that so far the OECD PPT rule and the genuine test from the CJEU case law are comparable. Also, the

43. See para. 38 of Cadbury Schweppes: 'it follows that the fact that in this case CS decided to establish CSTS and CSTI in the IFSC for the avowed purpose of benefiting from the favourable tax regime which that establishment enjoys does not in itself constitute abuse'. See also K. Lennaerts, 'The Concept of "Abuse of law" in the Case Law of the European Court of Justice in Direct Taxation', Maastricht Journal of European and Comparative Law 329 (2015)

44. CJEU 10 November 2011, C-126/10, Foggia.

45. For instance: the tax benefit is EUR 10 million less tax paid and the restructuring saves EUR 30,000 in reduced administrative costs (economic benefit).

46. I agree with Marres/De Groot that the OECD PPT includes a genuine/ economic reality test, which is comparable with the test that can be found in the case law of the CJEU regarding abuse of law and is contained in the anti-abuse provision of the Parent-Subsidiary Directive and in the Anti-Tax Avoidance Directive. See O.C.R. Marres and I.M. de Groot, De algemene antimisbruikbepaling in de moeder-dochterrichtlijn (deel 1), WFR 2015/7107, at 911 fact that under the economic reality test of the CJEU, a tax benefit does not constitute abuse as such, is the same as under the OECD PPT (under which referring only to the effects of an arrangement does not constitute abuse).

\subsubsection{No Artificiality Required?}

The economic reality test in the case law of the CJEU and the PPT rule, however, are not entirely the same: it is defendable that the OECD PPT rule is broader than the genuine test, and that there is not only treaty abuse under the OECD PPT rule in the case of an artificial arrangement, but also when there are economic reasons for a transaction but the tax benefits outweigh the economic reasons. As observed here above, it is clear from the Foggia case that abuse without an artificial arrangement is also possible under the abuse case law of the CJEU, so I expect that also on this point, the CJEU will not have a problem with this broader test. True, it cannot be argued with $100 \%$ certainty that the CJEU will permit such a broader test. The Foggia case concerned the Merger Directive and the anti-abuse provision in that directive does not contain an explicit artificiality test. The GAAR under the Anti-Tax Avoidance Directive $^{47}$ and the GAAR under the Parent-Subsidiary Directive in particular require that there must be artificiality if there is to be abuse. ${ }^{48}$ When the CJEU requires an artificiality test under the GAARs of these Directives, the PPT rule must be interpreted in conformity with these Directives, and thus be limited to artificial arrangements alone.

\subsubsection{Opinion in Literature}

In literature, doubts are raised as to whether the OECD PPT rule does contain an economic reality test and therefore, on this basis, it is defended that the OECD PPT rule is not in accordance with EU law. ${ }^{49}$ The European Commission has recommended to the Member States that in the case they include the OECD PPT rule in a tax treaty, the Member State insert herein an explicit 'genuine economic activity' test. ${ }^{50} \mathrm{I}$ emphasise that for the sake of clarity (and therefore the legal certainty) that this explicit inclusion of such a test should be welcomed, but as said, in my view, the PPT rule already contains such a test. When an arrangement is artificial, it will be, in most cases, also under OECD PPT rule, set up to obtain a tax benefit as one of the principal purposes. The only potential problem I see is that the PPT rule is broader (no artificiality required) compared to the GAAR in the Anti-Tax Avoidance

47. See Article 6 of Directive (EU) 2016/1164 of 12 July 2016 laying down rules against tax avoidance practices that directly affect the functioning of the internal market.

48. See Weber (2016), above n. 5 .

49. See Koriak, above n. 21, at 556

50. See 28 January 2016, no. C-2016 271 final; Commission Recommendation on the implementation of measures against tax treaty abuse, H\&l 2016/48. See also, with regard to the main purpose test in the OECDLOB provision, European Commission, Working document, Brussels 10 September 2014, Taxud D3, Working party IV - Direct taxation, OECD BEPS Action 6 draft: "Limitation On Benefits" provisions - interaction with EU law, at 10, published in Highlights \& Insights on European Taxation 2015/395. 
Directive and that under the Parent-Subsidiary Directive (see above).

\subsubsection{Conclusion}

To conclude: In light of the fact that the reasonableness test in the OECD PPT and abuse case law such as is applied by the CJEU itself in general are comparable, I doubt whether the CJEU would rule that such a test is in contravention of the EU principle of legal certainty. The only potential problem is that the PPT rule is broader (no artificiality required) as compared to the GAARs in the Anti-Tax Avoidance Directive and the Parent-Subsidiary Directive.

\subsection{Does the Reasonableness Test Lead to Too} Much Discretion of the Tax Administration? The question is whether the discretion the tax authorities have in applying the PPT rule is contrary to EU law. According to Kemmeren, ${ }^{51}$ the reasonableness test leads to too much uncertainty to taxpayers, and this is contrary not only to the requirement of legal certainty, but also to the Biehl case. ${ }^{52}$

\subsubsection{Biehl}

The Biehl case concerned a refund rule for too much tax paid. This rule gave no right to a refund of too much tax paid in the case that a taxpayer was only a resident taxpayer in Luxembourg part of the year, because he had taken up residence in the country or left it during the course of the tax year. The CJEU was of the opinion that this was a matter of a covert form of discrimination against nationality (paragraph 14):

Even though the criterion of permanent residence in the national territory referred to in connection with obtaining any repayment of an over-deduction of tax applies irrespective of the nationality of the taxpayer concerned, there is a risk that it will work in particular against taxpayers who are nationals of other Member States. It is often such persons who will in the course of the year leave the country or take up residence there.

During the hearing at the Court, the tax administration observed that there exists in Luxembourg law a noncontentious procedure allowing temporarily resident taxpayers to obtain repayment of an over-deduction of tax by adducing the unfair consequences, which the application Luxembourg tax law entailed for them. On this rule, the CJEU observed that, the Luxembourg government 'has not cited any provision imposing an obligation on the administration of the contributions to remedy in every case the discriminatory consequences arising for the application of the national provisions at issue' (emphasis added). In his Opinion (point 19), AG Darmon referred to the case law of the CJEU as 'mere administrative practices', 53 'which by their nature are

51. Kemmeren, above n. 2 .

52. CJEU 8 May 1990, C-175/88, Biehl.

53. CJEU 4 April 1974, 167/73, Commission/French Republic [1974] 359, paras. 46 and 47. alterable at will by the authorities and are not given the appropriate publicity, cannot be regarded as constituting the proper fulfilment of obligations under the Treaty'. 54

It follows from Biehl that the CJEU was of the opinion that the Luxembourg non-contentious procedure was not sufficiently legally binding (no obligation) to remove the contravention of EU law. In other words: the rule allowed too much discretionary power to the tax authorities. The tax authorities were able to apply the rule as they thought fit; there was no legal obligation.

\subsubsection{Biehl versus the Reasonableness Test}

The question is whether the discretion that the tax authorities had in Biehl is also of importance to the reasonableness test in the PPT rule.

Under the reasonableness test in the PPT rule, the tax authorities also have discretion, in the sense that they are not obliged to apply the PPT rule. In addition, based on the reasonableness test, they must substantiate their assessment on the basis of objective circumstances. Depending on the case, those will always be different circumstances. This, however, is a different situation to that under discussion in Biehl. In Biehl, there was a matter of a covert discrimination against nationality because taxpayers who exercised the free movement in Luxemburg could not claim a refund of too much tax paid. The Luxembourg government responded to this during the hearing of the Court that this disadvantage could be removed by the Luxembourg non-contentious procedure, but the CJEU dismissed this argument because there was no obligation of the tax authorities to apply that procedure. Due to this, the discrimination could thus continue to exist in certain situations.

The PPT rule as such is not contrary to EU law, but the application of the PPT rule can give rise to juridical double taxation, but this, as such, is not contrary to EU law (see on this in paragraph 5.3 here above). Nonapplication of the PPT rule does not lead to a contravention of EU law as such, because the non-application of the PPT rule leads to the application of the tax treaty, and precisely due to this, double taxation could be reduced.

As said, the reasonableness test only emphasises that the tax administration must substantiate their assessment that obtaining a benefit is one of the principal reasons of an arrangement on the basis of an objective analysis of objective circumstances. Assumptions are not permitted. Moreover, an assessment based merely on the effects of an arrangement is not sufficient.

To me, this would not seem to be contrary to the principle of legal certainty; The reasonableness test in fact underlines the principle of legal certainty: when a tax treaty is applicable, a taxpayer may invoke the benefits of this treaty, unless, but this must be based on an objective analysis of the facts and circumstances, that obtaining a tax benefit is one of the principal reasons of an arrangement.

54. CJEU 15 October 1986, Commission/Italy [1986] ECR 2945. 


\subsubsection{Discretion and EU-Lam}

The Leur-Bloem case, ${ }^{55}$ in my opinion, is of importance as regards the discretion the tax authorities have. ${ }^{56}$ From Leur-Bloem it is clear that a discretionary power of the tax administration not to apply EU law on the basis of evasion or abuse (in this case, the fiscal EU Merger Directive) is not permitted. It is clear that otherwise, the principle of legal certainty would be at risk. Specifically, with regard to advance consent or permits/ licences, which contain a deviation from the fundamental freedoms, the Court of Justice has developed case law on the basis of which it is clear that an assessment by an administrative body is permitted when 'based on objective, non-discriminatory criteria which are known in advance, in such a way as to circumscribe the exercise of the national authorities' discretion, so that it is not used arbitrarily'. ${ }^{57}$ We see a similar judgement regarding the discretionary power of administrative bodies in the area of directives, such as in Fazenda Pública. ${ }^{58}$ In this case, the Court of Justice considered with regard to the level of discretion of the tax administration under the Sixth VAT Directive,

[a] distinction must be drawn between the case where a Member State attempts to ensure the transposition of a directive by giving an administrative authority a discretionary power to apply its provisions, without circumscribing the administrative authority's discretion [which is not permitted], and the case, examined here, where the national legislature adopts, in a binding rule of law, the criteria set out in the directive and then leaves it to an administrative authority to implement them. [which is permitted]. ${ }^{59}$

If we apply this by analogy to the PPT rule, it cannot be said that the PPT rule is a rule that does not define the exercise of the national authorities' discretion. The fact that the answer to the question of when abuse is present cannot always be answered with $100 \%$ certainty beforehand (as it is dependent on the circumstance of each case) is inherent to the concept of 'abuse' itself. ${ }^{60}$

\section{Conclusion}

The OECD BEPS Action 6 report contains a PPT rule $^{61}$ for the purpose of combating abuse of tax treaties.
The PPT rule is applicable when it is reasonable to conclude' that obtaining a benefit is one of the principal purposes of an arrangement (the reasonableness test).

First, it is held in the literature that the reasonableness test of the PPT rule would be contrary to the European Union's principle of legal certainty. Reference is made in this regard to the judgments of the CJEU in SIAT and Itelcar. Second, it is held in literature that the OECD PPT rule gives the tax authorities too much discretion and, therefore, is not in line with EU law (based on the Biehl case). It is also held in literature that the OECD PPT rule does not contain a genuine economic activity test and therefore, is not in line with EU law.

In this contribution, I have defended that it does not follow from the cases SIAT and Itelcar that the reasonableness test is contrary to the principle of legal certainty. Those authors who hold a different view take, in my view, the relevant grounds of those judgments out of the context of the case. When they are read in the context of the case, one must come to the conclusion that those cases cannot be applied to the PPT rule.

The reasonableness test is also not contrary to EU law because this gives too much discretion to the tax authorities. The reasonableness test in fact underlines the principle of legal certainty: when a tax treaty is applicable, a taxpayer may invoke the benefits of this treaty, unless but this must be based on an objective analysis of the facts and circumstances - obtaining a tax benefit is one of the principal purposes of an arrangement.

Finally, in light of the fact that the reasonableness test in the OECD PPT rule and the abuse case law as applied by the CJEU itself in general are comparable, I doubt whether the CJEU would rule that such a test is in contravention of the EU principle of legal certainty or with another principle in EU law. The only potential problem I see is that the OECD PPT rule is broader (no artificiality required) compared to the GAARs in AntiTax Avoidance Directive and the Parent-Subsidiary Directive.

55. CJ 17 July 1997, case C-28/95 (Leur-Bloem), para. 44

56. This part is based on: Dennis Weber and Thidaporn Sirithaporn, 'Legal Certainty, Legitimate Expectations, Legislative Drafting, Harmonization and Legal Enforcement in European Tax Law', in Brokelind (ed.), Principle of Law: Function, Status and Impact in EU Tax Law, IBFD (2014), at 235.

57. See, amongst others, ECJ 12 July 2001, case C-157/99 (Smits en Peerbooms), ECR I-5473, para. 90.

58. CJ 14 December 2000, case C-446/98 (Fazenda Pública), ECR I-11 435.

59. Id., para. 34

60. See D. Weber, Tax Avoidance and the EX Treaty Freedoms, EUCOTAX, Kluwer Law International (2005), at 234.

61. See BEPS Action 6, above n. 1 . 